\title{
Suppression of Crosstalk in High-density Printed Circuit Boards by Coating Electroless-plated Ni-P Alloy Film on Signal Lines
}

\author{
M. Sonehara, S. Kayama, T. Sato, K. Yamasawa, and Y. Miura \\ Spin Device Technology Center, Shinshu University, 4-17-1 Wakasato, Nagano 380-8553, Japan
}

\begin{abstract}
High-density printed circuit boards (PCBs) with less than $50 \mu \mathrm{m} / 50 \mu \mathrm{m}$ line/space has been developed. Since the spacing between adjacent signal lines becomes very narrow in the PCBs, the crosstalk from electromagnetic interference in adjacent lines becomes serious. The authors have proposed a magnetic method of reducing the crosstalk. PCBs with electroless-plated Ni-P alloy film on the signal lines were fabricated. From an experiment using a PCB-TEG with a $130 \mu \mathrm{m} / 50 \mu \mathrm{m}$ line/space and $25-\mathrm{mm}$ line length, crosstalk was suppressed throughout a wide frequency range. In using $6-\mu \mathrm{m}$ thick $\mathrm{Ni}_{98} \mathrm{P}_{2.0}$ (wt.\%) alloy film, the suppressed crosstalk was up to $12 \mathrm{~dB}$ around 1 $\mathrm{GHz}$. However, the influence of transmission and reflection in the main signal line was very small.
\end{abstract}

Key words: crosstalk, electroless-plated $\mathrm{Ni}-\mathrm{P}$ alloy film, permeability, high density printed circuit board, finite difference time domain method

\section{信号線路に無電解 $\mathrm{Ni}-\mathrm{P}$ 合金めっき膜を被覆した 低クロストーク高密度プリント回路基板の作製と特性評価}

曾根原誠・加山慎二・佐藤敏郎・山沢清人 • 三浦義正

信州大学スピンデバイステクノロジーセンター, 長野県長野市若里 4-17-1（†380-8553）

\section{1. はじめに}

携帯電話に代表される各種情報通信機器は, 多機能・高 性能化が要求される一方で小型・軽量化も要求されている. その解決策の一つとして，プリント回路基板（Printed Circuit Board ; 以下，PCB と記述）の高密度実装化が挙 げられる. 最近では, 数十 $\mu \mathrm{m}$ のライン/スペース（以下， $L / S$ と記述）を有する微細配線が使用されている。また， スルーホールや層間ビアを設け立体的に配線した多層 PCB が主流となっている 1),2). しかしながら, 高密度化が 進むと図 1 に示す配線間容量 $C_{i j}$ および誘導結合 $M_{i j}$ による クロストークノイズが無視できなくなるため，その対策が 急務となっている ${ }^{3), 4}$.

クロストーク対策として，信号線路間にグランド配線を 配し，配線間容量 $C_{i j}$ によるクロストークを抑制する手法 5)が採用されているが, 高密度化に不利であり, 信号線路と グランド配線間の分布容量 $C_{i}, C_{j}$ が増大寸るため特性イン ピーダンスを低下させる問題がある. また, フェライトめ っき膜やナノグラニュラー薄膜などの磁性体によるノイズ 抑制シートの利用 6)が注目されているが, 多層 PCBにおけ る内部の信号線路への適用が困難で，層間クロストークの 抑制まではできない7).

筆者らは, 多層 PCBにおける内部の信号線路においても, 図 2(a)に示すような誘導結合 $M_{i j}$ による配線間クロストー クを抑制する手段として，図 2(b)に示すように信号線路間 に $\mathrm{Fe}$ 系アモルファス微粒子誘電体中分散型複合材料を充 填する方法 ${ }^{8)}$ を検討した. 平均粒径 $6 \mu \mathrm{m}$ の $\mathrm{SiO}_{2}$ で表面を 被覆された $\mathrm{Fe}-\mathrm{Si}-\mathrm{B}-\mathrm{Cr}$ アモルファス微粒子を $51 \mathrm{vol} \%$, エ ポキシ樹脂に分散させ, 幅 $50 \mu \mathrm{m}$ の $\mathrm{Cu}$ 信号線路間に充填 したところ，0.1〜8 [GHz] においてクロストークが 10〜20
[dB]抑制されることが明らかになった。更に高密度で微細 な $L / S$ をもつ PCB に適用するためには, 信号線路間に充 填する磁性微粒子の粒径を更に小さく, また粗大粒子が無 いものが望まれるが，適した磁性微粒子が無いのが現状で ある。

そこで，新たに図 $2(\mathrm{c})$ に示すように信号線路を無電解 $\mathrm{Ni}-\mathrm{P}$

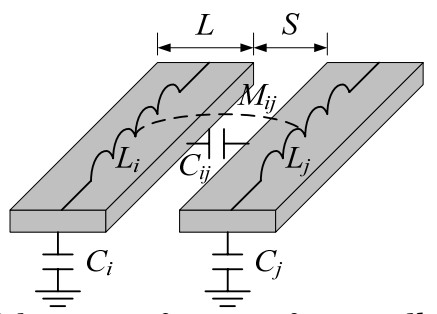

Fig. 1 Schematic of origin of crosstalk between adjacent signal lines.

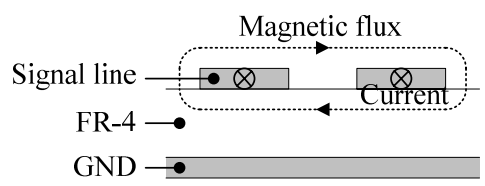

(a)

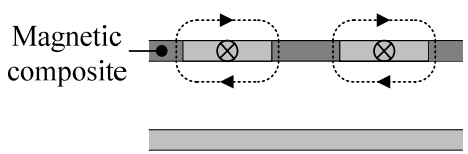

(b)

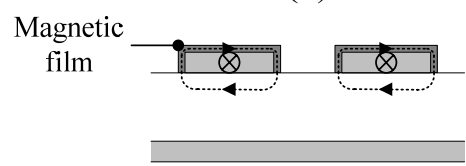

(c)

Fig. 2 Cross-sectional structure of PCBs (a) without crosstalk measures, (b) magnetic composite filled PCB, and (c) electroless-plated Ni-base alloy film coated PCB. 
合金めつき膜で被覆する方法を検討した，本方法は，前記 の信号線路間複合材料充填型に比べて, 信号線路上部から の漏洩磁束をシールドできるため, 同一層における信号線 路間クロストークのみならず層間クロストークに対しても 有効である.また, 現在 $\mathrm{Ni}-\mathrm{P}$ めっき膜は, 電極用 $\mathrm{Au}$ を形 成する際の置換 $\mathrm{Au}$ めつきの下地材料として使用されてい るため, プロセスコストに影響しない利点も有する.

本報告では, 初めに組成比の異なる無電解 Ni-P 合金めっ き膜の基礎特性を述べ, 続いて, 信号線路に無電解 Ni-P 合金めっき膜を被覆した PCBの作製方法, クロストークお よび伝送特性の測定結果について述べる。また, FDTD (Finite Difference Time Domain)法による電磁界解析の結 果も併記する.

\section{2. 無電解 $\mathrm{Ni}-\mathrm{P}$ 合金めつき膜の基礎特性}

本実験で使用した無電解 Ni-P 合金めつき膜の組成比は, $\mathrm{Ni}_{88} \mathrm{P}_{12}$ (wt.\%)(以下, 高リン $\mathrm{Ni}-\mathrm{P}$ と記述), $\mathrm{Ni}_{92.5} \mathrm{P}_{7.5}$ (wt.\%) (以下, 中リン $\mathrm{Ni}-\mathrm{P}$ と記述), $\mathrm{Ni}_{98} \mathrm{P}_{2.0}$ (wt.\%)（以下，低 リン $\mathrm{Ni}-\mathrm{P}$ と記述）の三種類とした. 無電解 $\mathrm{Ni}-\mathrm{P}$ 合金めっ き膜の基礎特性評価用の基板には，スライドガラス（100 $\mu \mathrm{m}$ 厚）を用い, それぞれ厚さ $6 \mu \mathrm{m}$ で無電解 $\mathrm{Ni}-\mathrm{P}$ 合金め っき膜を成膜した.ただし, 高リン Ni-P めっき膜は, スラ イドガラス上に成膜した際に剥離したため基礎特性が評価 できなかった。

\section{1 電気伝導率}

電気伝導率 $\sigma$ 測定は，4 端子抵抗計（日置電機(株）; 3220）を使用し, 測定された電気抵抗率 $\rho$ より算出した ${ }^{9)}$. 表 1 に中リンおよび低リン $\mathrm{Ni}-\mathrm{P}$ めっき膜の電気伝導率 $\sigma の$ 測定結果を示す.

表 1 より, 中リン Ni-P めっき膜の電気伝導率のの方が低 リン Ni-Pめっき膜に比べて低いことが分かる.中リン Ni-P めつき膜の電気伝導率 $\sigma$ の測定值は, 文献值 10) に比べ約 4 倍低く, 一方, 低リン $\mathrm{Ni}-\mathrm{P}$ めっき膜の電気伝導率のの測定 值は, 文献值に比べ約 2 倍低かった。 これは, 成膜された 無電解 Ni-P 合金めつき膜において $\mathrm{P}$ が偏析したため, 電

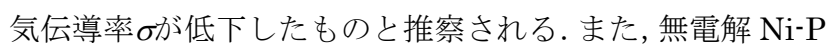
合金めっき膜の電気伝導率 気伝導率のの約 $1 \%$ あ゙あため, $\mathrm{Cu}$ 信号線路から $\mathrm{Ni}-\mathrm{P}$ め っき膜への信号電流の分流はほとんど無視できるものと考 えられる。

\section{2 静磁化曲線}

静磁化曲線の測定には, 振動試料型磁力計（理研電子(株) 製；BHV-55）を用いた. 図 3 に中リンおよび低リン $\mathrm{Ni}-\mathrm{P}$ めつき膜の静磁化曲線の測定結果を示す. また表 1 に各 $\mathrm{Ni}-\mathrm{P}$ めつき膜の飽和磁化 $M_{\mathrm{s}}$ の測定結果を示す.

図 3 および表 1 より, 中リン $\mathrm{Ni}-\mathrm{P}$ めつき膜の飽和磁化 $M_{\mathrm{s}}$ の方が低リン $\mathrm{Ni}-\mathrm{P}$ めっき膜に比べて低いことが分かる. また各 Ni-P 合金めっき膜において, 膜面内方向では, 静磁 化曲線は等方性を示した.
Table 1 Measured results from electroless-plated Ni-base alloy film.

\begin{tabular}{|c|c|c|c|}
\hline \multicolumn{2}{|l|}{ Type } & $\mathrm{Ni}-\mathrm{P}(7.5 w \mathrm{w} . \%)$ & $\mathrm{Ni}-\mathrm{P}(2.0$ wt.\%) \\
\hline \multicolumn{2}{|c|}{ Average constitution [wt.\%] } & $\mathrm{Ni}_{92.5} \mathrm{P}_{7.5}$ & $\mathrm{Ni}_{98} \mathrm{P}_{2.0}$ \\
\hline \multicolumn{2}{|c|}{ Electrical conductivity $\sigma[\mathrm{S} / \mathrm{m}]$} & $0.412 \times 10^{6}$ & $0.911 \times 10^{6}$ \\
\hline \multicolumn{2}{|c|}{ Saturation magnetization $M_{\mathrm{s}}[\mathrm{T}]$} & 0.067 & 0.156 \\
\hline \multirow{2}{*}{$\begin{array}{c}\text { Complex permeability } \\
\text { @ } 1 \mathrm{GHz}\end{array}$} & $\mu$ & 1.18 & 3.24 \\
\hline & $\mu$ & 0 & 1.25 \\
\hline
\end{tabular}

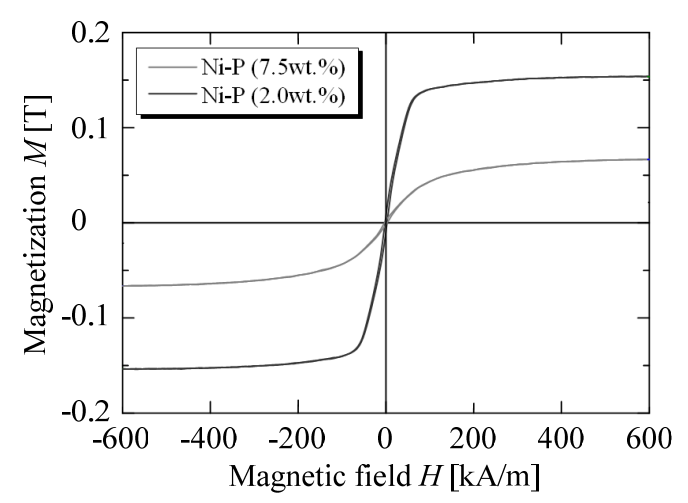

Fig. 3 Static magnetization curves in two types of electroless-plated Ni-P alloy films.

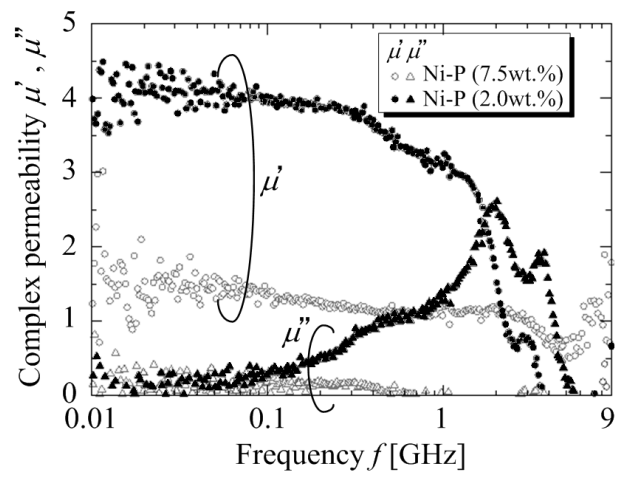

Fig. 4 Dependence of complex permeability $\mu$ and $\mu$ ' on frequency in two types of electroless-plated Ni-P alloy films.

\section{3 複素比透磁率の周波数特性}

複素比透磁率の周波数特性の測定には, 超高周波透磁率 測定装置（凌和電子(株)製; PMM-9G1）を用いた ${ }^{11)}$. 図 4 に中リンおよび低リン $\mathrm{Ni}-\mathrm{P}$ めっき膜の複素比透磁率の周 波数特性の測定結果を示す. また表 1 に各 $\mathrm{Ni}-\mathrm{P}$ めっき膜 の $1 \mathrm{GHz}$ における複素比透磁率の実部 $\mu$ および虚部 $\mu$ ”測 定結果を示す.

図 4 より, 中リン $\mathrm{Ni}-\mathrm{P}$ めっき膜においては, $2 \mathrm{GHz}$ 以 下で複素比透磁率の実部 $\mu$ は 1.1〜 1.5 とほぼ一定であり, また，虚部 $\mu$ ”ほほぼ 0 であり，高周波磁気損失は小さいと 考えられる. 一方, 低リン Ni-P めっき膜においては, 0.3 $\mathrm{GHz}$ 以下で複素比透磁率の実部 $\mu$ はおよそ 4 程度と中リン $\mathrm{Ni}-\mathrm{P}$ めっき膜に比べて約 2 倍高い值を示した. しかしなが ら, $0.3 \mathrm{GHz}$ 以上では, 複素比透磁率の実部 $\mu$ は急激に低 下し，虚部 $\mu$ は増加することが分かった。これは，うず電 流および自然共鳴による損失であると考えられる. 


\section{3. クロストーク測定用 PCB の作製方法}

\section{1 クロストーク測定用 PCB の設計 · 寸法}

クロストーク測定用 PCB の概観図を図 5(a)に, 寸法を同 図(b)に示す. 配線パターンは, 信号線路長 1 が $25 \mathrm{~mm}$, 信 号線路幅 $L$ が $130 \mu \mathrm{m}$ で, 信号線路間スペーシング $S$ が 50 , $100[\mu \mathrm{m}]$ の二種類とした. 図 5 の中央の直線な信号線路が 主線路であり，その両側が副線路である。なお，エッチン グバランスを取るために最外にダミー線路を配した。信号 線路および基板背面のグランドの厚さは $32 \mu \mathrm{m}$, 誘電体 (ガ ラスエポキシ; 以下，FR-4 と記述）の厚さは $100 \mu \mathrm{m}$ であ る. 波長短縮効果も考慮すると, 本クロストーク測定用 $\mathrm{PCB}$ は, $2 \mathrm{GHz}$ まで測定可能である. また図 5 中の左右に それぞれ 4 つの円形は下部グランドプレーンとのスルーホ ールであり, 上部および下部グランドは電気的に接続され ている.

\section{2 信号線路への無電解 Ni-P 合金めっき膜の成膜}

信号線路への無電解 $\mathrm{Ni}-\mathrm{P}$ 合金めつき膜の成膜は，表 2 の条件で酸性脱脂, 酸処理, エッチング, $\mathrm{Pd}$ 触媒付与の順 で前処理を行ない, 表 3 の条件で無電解 Ni-P めつきを行 なった ${ }^{12)}$. なお, プローブとの接触部は, $\mathrm{Ni}-\mathrm{P}$ めつき膜を 成膜していない.

$\mathrm{Ni}-\mathrm{P}$ めつき膜の組成比は, 前章の高, 中, 低リンの三種 類で，目標膜厚はそれぞれ $2,4,6[\mu \mathrm{m}]$ とした。表 4 に, 各 $\mathrm{Ni}-\mathrm{P}$ めつき膜に対する平均膜厚を示す. 表 4 より, 平 均膜厚は目標膜厚に対し，5\%程度の誤差で概水目標膜厚 に近い厚さであった. 以降は, $\mathrm{Ni}-\mathrm{P}$ めっき膜の膜厚 $t_{\mathrm{Ni} i} \mathrm{P}$ は, 目標膜厚で記述する.

\section{FDTD 法による解析方法}

信号線路に無電解 $\mathrm{Ni}-\mathrm{P}$ 合金めつき膜を被覆した PCB の クロストークの抑制効果を解析するために，FDTD 法を用 いた電磁界解析ソフトウェア MAGNA/TDM ((株)CRC ソ リューションズ製）を用いた。

図 6 に解析モデルを示す. Ni-P めっき膜が無い解析モデ ルは, Ni-P めっき膜を Air とした. 図 6 の解析モデルと図
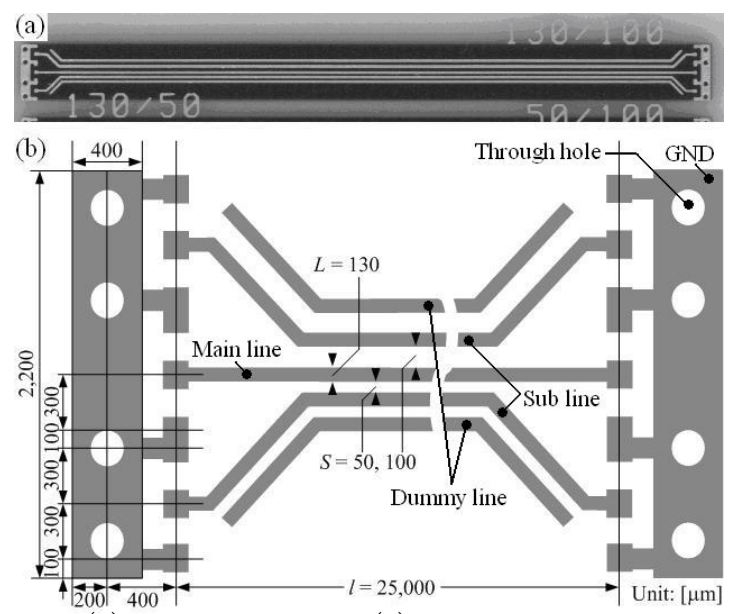

Fig. 5 (a) Photograph and (b) dimensions of PCB used to measure crosstalk.
5 の実寸法と一致していない理由は, 解析セルの $\mathrm{y}$ 方向お よび $\mathrm{z}$ 方向の長さ $\Delta y, \Delta z$ $6 \mu \mathrm{m}$ に設定したためであるが, 解析モデルの寸法と実寸法との䛊差率は 4 \%程度なので, 解析結果に影響を及ぼさないものとした。

表 5 に代表として, 信号線路間スペーシング $S=96 \mu \mathrm{m}$, 周波数 $f=1 \mathrm{GHz}$ の場合の解析条件を示す. なお, 各表の *印は, 周波数 $f$ に応じて変わる数值を表している. 給電 方法は, $+\mathrm{z}$ 方向に電圧を印加した. 入力波形には $\sin$ 波を 用い, 励振持続時間 $t_{\mathrm{e}}=4 \mathrm{~ns}$ とした. セルサイズは, 誘電 体内部での波長短縮効果を考慮しても波長に比べ十分小さ い值を設定し, 周波数 $f=1 \mathrm{GHz}$ では, 解析セルの $\mathrm{x}$ 方向 （長手方向）の長さ $\Delta x=750 \mu \mathrm{m}$ とした. 解析空間の境界 条件は，最小 $\mathrm{Z}$ 面を電気壁（GND）とし，それ以外の 5 つ の面は全て PML (Perfectly Matched Layer)とした. PML のパラメータは, 電気伝導率の分散次数を 2 , 垂直入射時 の減衰率を-140 dB，PML の層数を 6 とした。 これにより 解析空間のサイズは, 解析モデルのサイズに比べ信号線路 方向で約 1.2 倍であるが，境界面での反射の影響は受けな いものであった.

表 6 に解析で用いた各層の物性值を示す. 誘電体 FR-4 の比誘電率は 4.6 , 信号配線の電気伝導率は $59.6 \times 10^{6} \mathrm{~S} / \mathrm{m}$

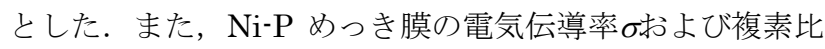
透磁率の実部 $\mu$ および虚部 $\mu$ ”，前章の測定結果の值を用 いた. 解析結果は, 第 6 章のクロストーク測定用 PCB の 測定結果と共に示す.

Table 2 Pretreatment conditions for electroless Ni-P alloy plating.

\begin{tabular}{l|c|c}
\hline \multicolumn{1}{c|}{ Process } & Temperature $\left[{ }^{\circ} \mathrm{C}\right]$ & Time $[\mathrm{min}]$ \\
\hline 1. Acid degreasing & 40 & 1 \\
\hline 2. Acid treatment & R. T. & 1 \\
\hline 3. Etching & 25 & 5 \\
\hline 4. Pd catalyzing & 25 & 5 \\
\hline
\end{tabular}

Table 3 Electroless plating conditions for Ni-P alloy.

\begin{tabular}{l|c|c|c}
\hline \multicolumn{1}{c|}{ Sample name } & $\mathrm{Ni}-\mathrm{P}(12$ wt.\%) & $\mathrm{Ni}-\mathrm{P}(7.5$ wt.\%) & $\mathrm{Ni}-\mathrm{P}(2.0$ wt.\%) \\
\hline $\begin{array}{l}\text { Average composition } \\
\text { of electroless plating } \\
\text { film [wt.\%] }\end{array}$ & $\mathrm{Ni} 88 \mathrm{P}_{12}$ & $\mathrm{Ni}{ }_{92.5} \mathrm{P}_{7.5}$ & $\mathrm{Ni} 98 \mathrm{P}_{2}$ \\
\hline Bath temperature [ $\left.{ }^{\circ} \mathrm{C}\right]$ & 82 & 80 & 90 \\
\hline $\mathrm{pH}$ & 4.8 & 4.6 & 5.0 \\
\hline Ni density [g/L] & 6.0 & 5.0 & 5.5 \\
\hline Reductant & \multicolumn{3}{|c}{ Hypophosphorus acid } \\
\hline Coating ratio [nm/s] & 3.0 & 2.8 & 5.6 \\
\hline
\end{tabular}

Table 4 Mean thickness of electroless-plated Ni-P alloy film.

\begin{tabular}{|c|c|c|c|}
\hline & \multicolumn{3}{|c|}{ Mean thickness $[\mu \mathrm{m}]$} \\
\hline Target thickness [ $[\mu \mathrm{m}]$ & Ni-P(12 wt.\%) & $\mathrm{Ni}-\mathrm{P}(7.5$ wt.\%) & $\mathrm{Ni}-\mathrm{P}(2.0$ wt. $\%)$ \\
\hline 2 & 2.33 & 2.25 & 2.32 \\
\hline 4 & 3.85 & 3.94 & 4.37 \\
\hline 6 & 5.92 & 6.21 & 6.31 \\
\hline
\end{tabular}




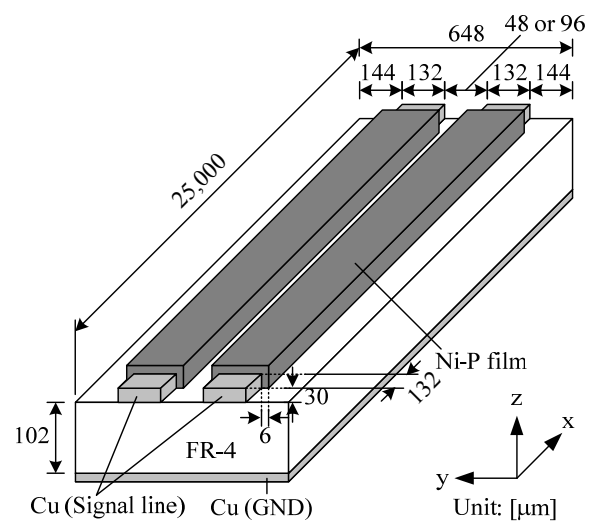

Fig. 6 Model for analysis of PCB.

Table 5 Analysis conditions.

\begin{tabular}{l|c|c}
\hline \multirow{4}{*}{ Analysis area } & Size & $30,750 \times 648 \times 252[\mu \mathrm{m}]^{*}$ \\
\cline { 2 - 3 } & & $\begin{array}{c}5 \text { planes, } 2 \text { degrees, } \\
\text { Damping factor: }-140 \mathrm{~dB}, \\
\text { Number: } 6\end{array}$ \\
\hline \multirow{4}{*}{ Cells } & Size & $\Delta x=750^{*}, \Delta y=\Delta z=6[\mu \mathrm{m}]$ \\
\cline { 2 - 3 } & Number & $185,976^{*}$ \\
\cline { 2 - 3 } Calculated steps & Shape & Rectangular parallel piped \\
\hline \multirow{2}{*}{ Feed } & Time $\Delta t$ & 7 fs* \\
\cline { 2 - 3 } & Number & $571,428^{*}$ \\
\cline { 2 - 3 } & Type & Voltage, $\mathrm{z}$ axis, sin wave \\
\cline { 2 - 3 } & Excitation time & $4 \mathrm{~ns}^{*}$ \\
\hline
\end{tabular}

Table 6 Material value in each layer.

\begin{tabular}{c|l|l|l|c}
\hline Layer & $\mu$ & $\mu$ & $\dot{\varepsilon}^{\xi}$ & $\sigma[\mathrm{S} / \mathrm{m}]$ \\
\hline $\mathrm{Ni}-\mathrm{P}(7.5$ wt.\% $)$ & $1.18^{*}$ & 0 & 1 & $0.412 \times 10^{6}$ \\
\hline $\mathrm{Ni}-\mathrm{P}(2.0$ wt.\% $)$ & $3.24^{*}$ & $1.25^{*}$ & 1 & $0.911 \times 10^{6}$ \\
\hline $\mathrm{Cu}$ & 1 & 0 & 1 & $59.6 \times 10^{6}$ \\
\hline FR-4 & 1 & 0 & 4.6 & 0 \\
\hline Air & 1 & 0 & 1 & 0 \\
\hline
\end{tabular}

\section{5. クロストーク測定用 PCB の測定方法}

PCB の信号線路間におけるクロストークおよび伝送特 性の評価には, 図 7 に示寸ように 4-port 高周波ネットワー クアナライザ（ADVANTEST 製；R3767CG OPT14），同 軸ケーブル (ADVANTEST 製; A01253-030)，GSG デュ アルプローブ（GGB INDUSTRIES INC.製; picoprobe 40A-GSG-300/ 40A-GSG-300-D-700）を用い，図 8 に示さ れる主線路および副線路における $S$ パラメータを測定した。 同図の $S_{11}$ は反射係数， $S_{21}$ は透過係数で，これらを伝送特 性として評価した。一方， $S_{31}$ は近端クロストーク， $S_{41}$ は 遠端クロストークとし，これらをクロストークとして評価 した。なお，測定前には，プローブ用校正基板（GGB INDUSTRIES INC.製; Calibration Substrate Part\# CS-9）を用いて校正した．測定時の測定対象ではない副線 路およびダミ一線路には何も接続せず，また各配線の配線 間容量 $C_{\mathrm{j}}$ や配線とグランド配線間の分布容量 $C, G$ は無 視できるほど小さいものであった.

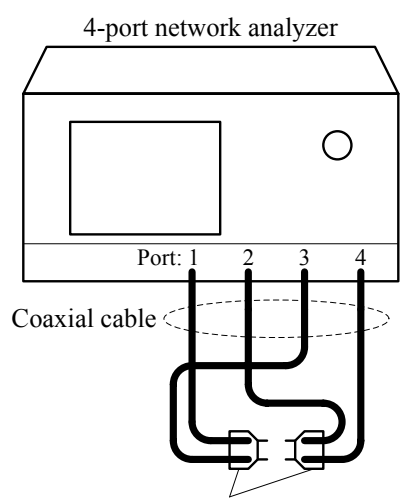

GSG dual probe

Fig. 7 Schematic of the measurement system for $S$ parameters in PCB.

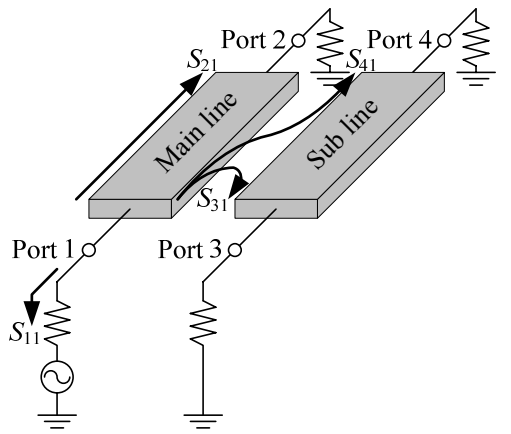

Fig. $8 \overline{\bar{D}}$ efinition of $S$ parameters in PCB.

\section{6. クロストーク測定用 PCB のクロストーク および伝送特性の測定結果}

\section{1 信号線路への無電解 $\mathrm{Ni}-\mathrm{P}$ 合金めっき膜の成膜}

図 9 に組成比の異なる三種類の無電解 Ni-P 合金めっき 膜（ $t_{\mathrm{Ni}-\mathrm{P}}=6 \mu \mathrm{m} ）$ をそれぞれ信号線路に被覆した PCB（ $L$ $/ S=130 / 50[\mu \mathrm{m}])$ の伝送特性およびクロストークの周 波数特性の測定結果を示す. 比較として, Ni-P めっき膜を 被覆しない PCB の測定結果も示寸。また，前記の FDTD 法によって得られた解析結果も併記するが，測定試料のば らつきや測定誤差などの影響で測定結果とは, 最大で 10 $\mathrm{dB}$ 程度の不一致は見られたが, 各パラメータの周波数特性 の傾向は概ね一致した。

図 9(a)，(b)より，P 含有量の減少に伴い，反射係数 $S_{11}$ および透過係数 $S_{21}$ は低下寸る傾向が示された。これは, 図 4 で示した Ni-P めっき膜の複素比透磁率の虚実 $\mu$ によ る磁気損失の増大や複素比透磁率の実部 $\mu$ にる線路イン ダクタンスの増大による特性インピーダンスが変化したた めと考えられる。しかしながら，低リン Ni-P めっき膜にお いて, $1 \mathrm{GHz}$ で反射係数 $S_{11}$ は約 $5 \mathrm{~dB}$, 透過係数 $S_{21}$ は約 $0.25 \mathrm{~dB}$ 程度の減少であり, 携帯電話の $\mathrm{RF}$ 回路の受動部 品の挿入損失限界が $0.5 \mathrm{~dB}$ であることからも，伝送特性に は大きな影響を与えないと考えられる.

同図(c)より，近端クロストーク $S_{31}$ に対しては, Ni-P め っき膜を被覆すると増加する傾向が示されたが，低リン $\mathrm{Ni}-\mathrm{P}$ めっき膜でも $1 \mathrm{GHz}$ で約 $2 \mathrm{~dB}$ 程度の増加であった. 


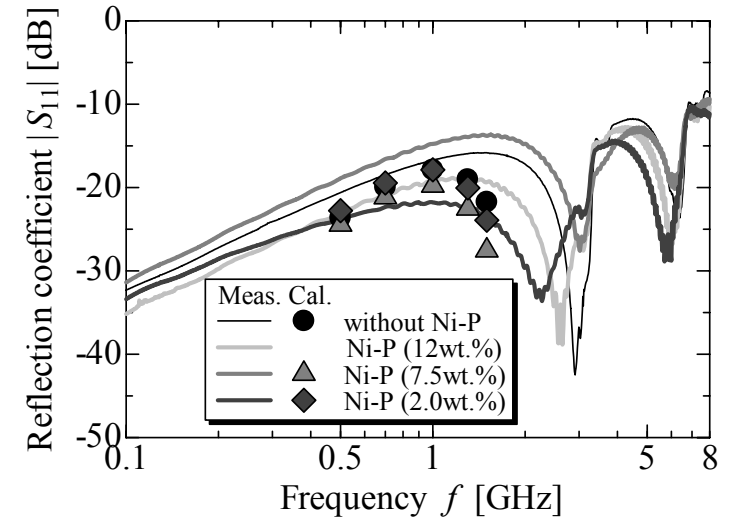

(a) Reflection coefficient $S_{11}$

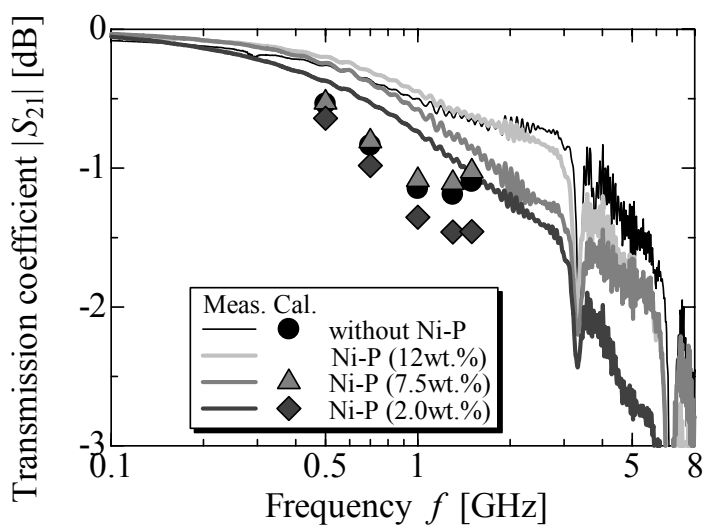

(b) Transmission coefficient $S_{21}$

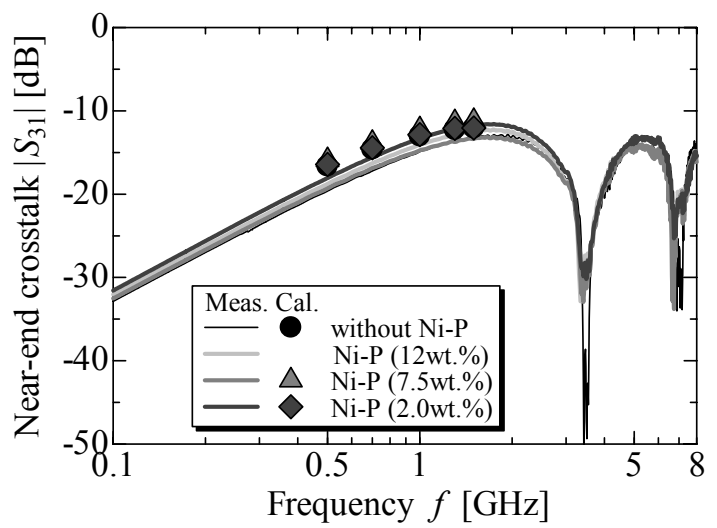

(c) Near-end crosstalk $S_{31}$

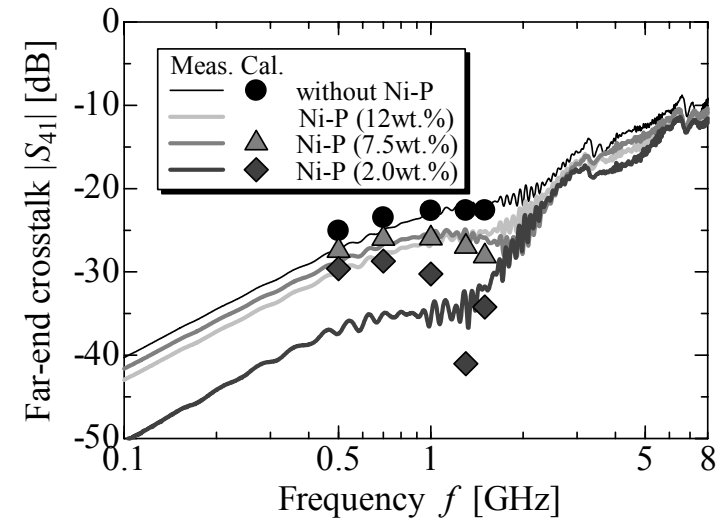

(d) Far-end crosstalk $S_{41}$

Fig. 9 Relation between $S$ parameters ((a) reflection and (b) transmission coefficients, and (c) near-end and (d) far-end crosstalk) and constitution of Ni-P film in PCBs.

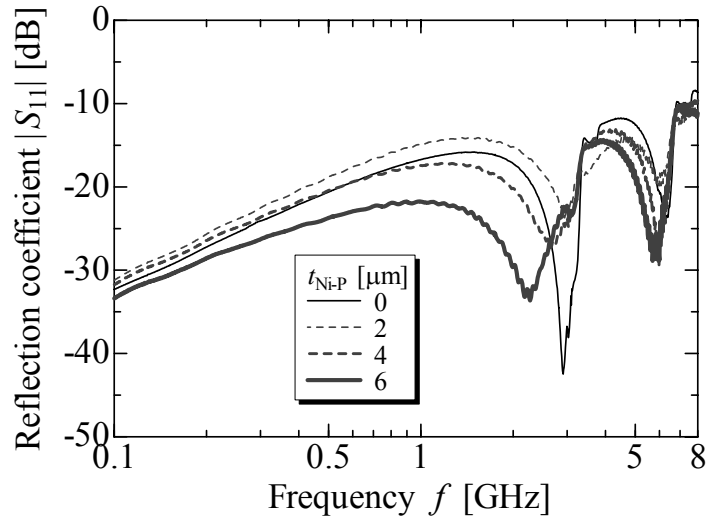

(a) Reflection coefficient $S_{11}$

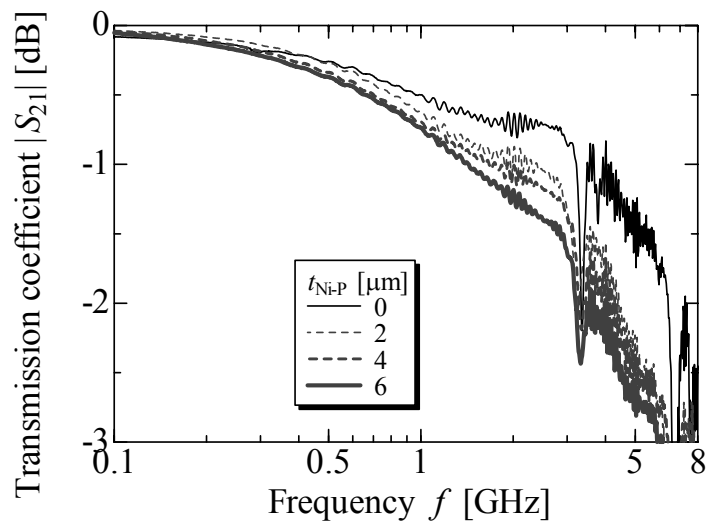

(b) Transmission coefficient $S_{21}$

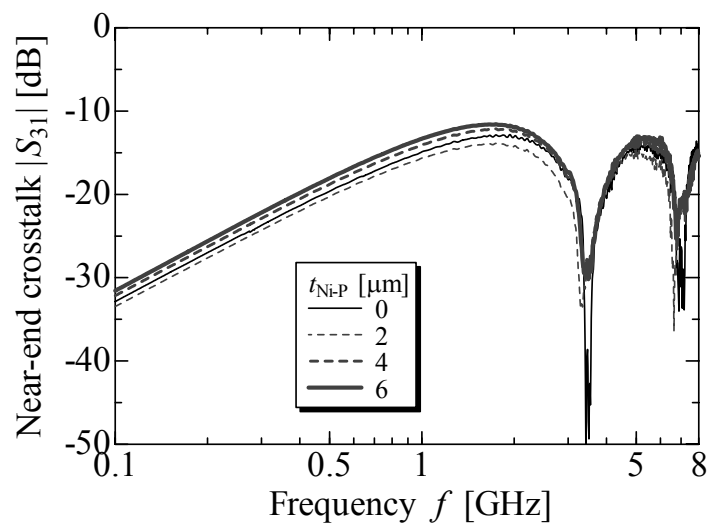

(c) Near-end crosstalk $S_{31}$

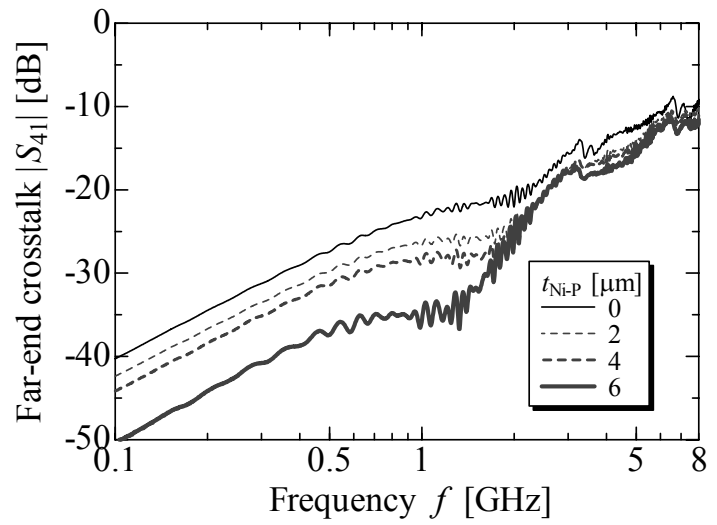

(d) Far-end crosstalk $S_{41}$

Fig. 10 Relation between $S$ parameters ((a) reflection and (b) transmission coefficients, and (c) near-end and (d) far-end crosstalk) and thickness of Ni-P (2.5wt.\%) film in PCBs. 
一方，同図(d)より， $\mathrm{P}$ 含有量の減少に伴い，遠端クロスト 一ク $S_{41}$ は低下寸ることが分かる。これは，P 含有量が減 少すると透磁率が高くなり, 磁気シールド効果がより向上 したためと考えられる。低リン $\mathrm{Ni}-\mathrm{P}$ めき膜において，1 $\mathrm{GHz}$ で遠端クロストーク $S_{41}$ は約 $12 \mathrm{~dB}$ 減少した. 近端ク ロストーク $S_{31}$ は, 駆動線路のドライバと受動線路のレシ 一バが物理的に近くにあるために遠端クロストーク $S_{41}$ よ りも大きく，以前はクロストークとは前者を指すことが多 く, 後者は重要視されていなかった. しかしながら, 近年 では, バス伝送の多用によって複数の駆動線路から同じタ イミングで伝送される信号が重畳するようになり，特に一 方に信号源，他方に負荷という一般的な回路である場合， 近端クロストーク $S_{31}$ よりも遠端クロストーク $S_{41}$ の方を 抑制する要請がある13)ことから，本手法は適しているとい える.

\section{2 低リン Ni-P めっき膜の膜厚依存性}

図 10 に低リン組成の無電解 $\mathrm{Ni}-\mathrm{P}$ 合金めつき膜の膜厚 $\left(t_{\mathrm{Ni}-\mathrm{P}}=0,2,4,6[\mu \mathrm{m}]\right)$ に対する信号線路上 $\mathrm{Ni}-\mathrm{P}$ めっき 膜被覆 PCB（ $L / S=130 / 50[\mu \mathrm{m}])$ の伝送特性およびク ロストークの周波数特性の測定結果を示す.

図 10(a), (b)より, Ni-P めっき膜の膜厚 $t_{\mathrm{Ni} i \mathrm{P}}$ が厚くなる に伴い, 反射係数 $S_{11}$ および透過係数 $S_{21}$ は低下する傾向が 示された. これは, $\mathrm{Ni}-\mathrm{P}$ めつき膜の膜厚 $t_{\mathrm{Ni} \text { - } \mathrm{P}}$ を厚くするこ とで, 図 4 で示した Ni-P めっき膜の複素比透磁率の虚実 $\mu$ ” による磁気損失の増大や複素比透磁率の実部 $\mu$ にる線路 インダクタンスの増大による特性インピーダンスの変化が より顕著に表れたものと考えられる.

同図(c)より, Ni-P めっき膜の膜厚 $t_{\mathrm{Ni} i \mathrm{P}}$ を厚くするに伴 い, 近端クロストーク $S_{31}$ は増加する傾向が示されたが, $t_{\mathrm{Ni}-\mathrm{P}}=6 \mu \mathrm{m}, 1 \mathrm{GHz}$ で約 $2 \mathrm{~dB}$ 程度の増加であった. 一方, 同図(d)より, Ni-P めっき膜の膜厚 $\iota_{\mathrm{Ni} i \mathrm{P}} \mathrm{P}$ 厚くなるに伴い, 遠端クロストーク $S_{41}$ は低下することが分かる．これは， $\mathrm{Ni}-\mathrm{P}$ めつき膜の膜厚 $t_{\mathrm{Ni}-\mathrm{P}}$ が厚くなると, 磁気シールド効果 がより向上したためと考えられる.

\section{3 信号線路間スペーシング $S$ 依存性}

図 11 に組成比の異なる三種類の無電解 $\mathrm{Ni}-\mathrm{P}$ 合金めっき 膜 $\left(t_{\mathrm{Ni}-\mathrm{P}}=6 \mu \mathrm{m}\right)$ をそれぞれ信号線路に被覆した PCB（L $\zeta S=130 / 100[\mu \mathrm{m}])$ の遠端クロストーク $S_{41}$ の周波数特

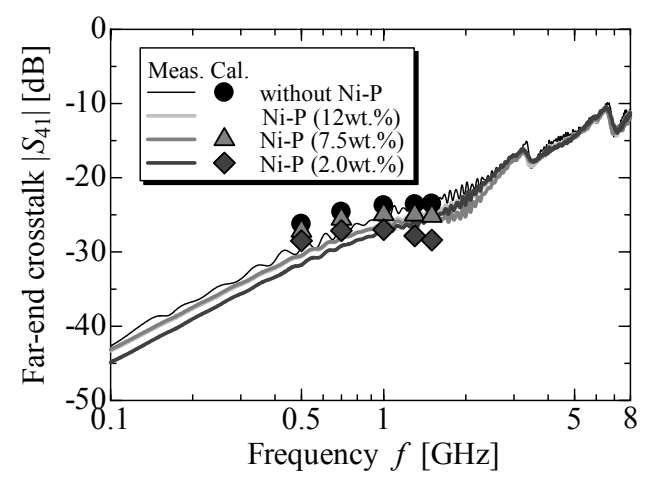

Fig. 11 Relation between far-end crosstalk $S_{41}$ and constitution of Ni-P film in PCBs.
性の測定結果を示す. 比較として, Ni-P めつき膜を被覆し ない PCB の測定結果も示す。また，FDTD 法によって得 られた解析結果も併記するが，測定結果と概ね一致した。

図 11 より，低リン $\mathrm{Ni}-\mathrm{P}$ めっき膜においても，1 GHz で 遠端クロストーク $S_{41}$ は約 $3 \mathrm{~dB}$ しか減少せず, 図 9(d)の信 号線路間スペーシング $S=50 \mu \mathrm{m}$ の場合に比べ減少しなか った。これは，信号線路間スペーシング $S$ が狭い場合，信 号線路間の電磁結合が強く, Ni-P めつき膜による磁気シー ルド効果がより顕著に表れたと考えられ，PCBの高密度化 に対して，本手法は有用であると考えられる.

\section{7. まとめ}

以上より,信号線路に無電解 $\mathrm{Ni}$ 基合金めっき膜を被覆し た PCB は被覆しない PCB に比べ，伝送特性は $1 \mathrm{GHz}$ で 約 $0.25 \mathrm{~dB}$ の低下だけで大きな影響を与えず，信号線路間 スペーシングが狭い高密度 PCB ほど遠端クロストークを 大幅に抑制でき， $1 \mathrm{GHz}$ で約 $12 \mathrm{~dB}$ 低下できることが明ら かになった．信号線路間複合材料充填型に比べクロストー ク抑制は劣るため, 今後 $\mathrm{Ni}-\mathrm{P}$ 組成比や膜厚, $\mathrm{Ni}_{99.8} \mathrm{~B}_{0.2}$ (wt.\%)めっき膜への変更などを検討する予定である.

謝辞 無電解 $\mathrm{Ni}-\mathrm{P}$ 合金めっき膜は，野口 真 氏（大和電機 工業(株)）にご協力頂き成膜した．複素比透磁率の周波数特 性の評価は，池田 賢司 氏（太陽誘電(株)）にご協力頂きま した.また，4-port 高周波ネットワークアナライザは日置電 機(株)様, 4 端子抵抗計は信州大学工学部情報工学科 森迫・ 劉研究室より拝借した. 以上の皆様に厚く御礼申し上げます.

\section{References}

1) K. C. Yung, H. Liem, H. Choy, and T. M. Yue: J. Appl. Poly. Sci., 116, pp.2348-2358 (2010).

2) K. Takagi: Yokuwakaru Printed Circuit Boards no Dekirumade -Second edition- (in Japanese), (Nikkan Kogyo Shinbunsya, Tokyo, 2007).

3) J. Xiaosong and Z. Runjing: Proc. Int. Conf. Electronic Measurement and Instruments 2007 (ICEMI'07), pp.2-437-2-440 (2007).

4) Y. Kudo, T. Tobana, and T. Sasamori: IEICE Trans. Commun., 92, 1, pp.296-303 (2009).

5) T. Maeno, Y. Sakurai, T. Unou, K. Ichikawa, and O. Fujiwara IEEJ Trans. Fund. Mater, 128, 11, pp.657-662 (2008).

6) H. Ono, T. Ito, S. Yoshida, Y. Takase, O. Hashimoto, and Y. Shimada: IEEE Trans. Magn., 40, 4(2), pp.2853-2857 (2004).

7) T. Maruyama, M. Sonehara, K. Ikeda, T. Sato, K. Yamasawa, and Y. Miura: The Papers of Tech. Meeting on Magn., IEE Japan, MAG-10-201, pp. 11-16 (2010).

8) S. Kayama, M. Sonehara, T. Sato, K. Yamasawa, and Y. Miura: IEEE Trans. Magn., 45, 10, pp.4801-4803 (2009).

9) M. Smits: Bell Syst. Tech. J., 37, 5, pp.711-718 (1958).

10) B. Ro: Corrosion-Resistant Plating and Chemical Plating (in Japanese), (Nikkan Kogyo Shinbunsya, Tokyo, 1961).

11) M. Yamaguchi, Y. Miyazawa, K. Kaminishi, and K.-I. Arai: Trans. Magn. Soc. Jpn., 3, 4, pp.137-140 (2003).

12) M. Sonehara, S. Noguchi, T. Kurashina, T. Sato, K. Yamasawa, and Y. Miura: IEEE Trans. Magn., 45, 10, pp. 4173-4175 (2009).

13) Y. Usui: Boards Sekkeisya no Tameno Bunpu Josu Kairo no Subete -Second edition- (in Japanese), (Self-publishing, 2009).

2010年9月10日受理，2011年1月6日採録 